\title{
The bats of Rio Grande do Norte state, northeastern Brazil
}

\author{
Juan Carlos Vargas-Mena ${ }^{1 *} \mathbb{D}^{\mathbb{D}}$, Kleytone Alves-Pereira ${ }^{2}$, Marília Abero Sá Barros ${ }^{3}$, Eder Barbier ${ }^{3} \mathbb{D}$, Eugenia \\ Cordero-Schmidt ${ }^{1}$,Sergio Maia Queiroz Lima ${ }^{4}$, Bernal Rodríguez-Herrera ${ }^{5}$ \& Eduardo Martins Venticinque ${ }^{l}$ \\ ${ }^{1}$ Universidade Federal do Rio Grande do Norte, Departamento de Ecologia, Centro de Biociências, Campus \\ Lagoa Nova, 59072-970, Natal, RN, Brasil \\ ${ }^{2}$ Universidade Federal do Rio Grande do Norte, Departamento de Psicobiologia, Centro de Biociências, \\ Campus Lagoa Nova, 59072-970, Natal, RN, Brasil \\ ${ }^{3}$ Universidade Federal de Pernambuco, Departamento de Zoologia, Centro de Biociencias, Rua Nelson Chaves, \\ Cidade Universitária, 50670-901, Recife, PE, Brasil \\ ${ }^{4}$ Universidade Federal do Rio Grande do Norte, Departamento de Botânica e Zoologia, Centro de Biociências, \\ Campus Lagoa Nova, 59072-970, Natal, RN, Brasil \\ ${ }^{5}$ Universidad de Costa Rica, Escuela de Biología, 2060, Montes de Oca, San José, Costa Rica \\ *Corresponding author: Juan Carlos Vargas-Mena, e-mail: jcvargasmena@gmail.com
}

VARGAS-MENA, J. C., ALVES-PEREIRA, K., BARROS, M. A. S., BARBIER, E., CORDERO-SCHMIDT, E., LIMA, S. M. Q., RODRÍGUEZ-HERRERA, B., VENTICINQUE, E. M. The bats of Rio Grande do Norte state, northeastern Brazil. Biota Neotropica. 18(2): e20170417. http://dx.doi.org/10.1590/1676-0611-BN-2017-0417

\begin{abstract}
Rio Grande do Norte is one of the smallest states in Brazil but has a rich diversity of ecosystems, including Caatinga vegetation, remnants of Atlantic Forest, coastal habitats, mangroves and large karstic areas with caves. However, its chiropteran fauna is little known, and the state contains conspicuous gaps of information on the occurrence and distribution of bats in Brazil. In order to reduce this information gap, based on a review of scientific literature and regional mammal collections, we list 42 species of bats, including new occurrences for 13 species and discussion on their conservation status. Results show that more than half (54\%) of the recorded species are phyllostomid bats, and about one third of the bats in the state roosts in underground cavities. The Caatinga harbored the highest bat richness in the state, including the occurrence of four vulnerable species (Furipterus horrens, Lonchorhina aurita, Natalus macrourus and Xeronycteris vieirai). The Atlantic Forest needs to be more sampled, including mangroves, coastal habitats and areas of Caatinga in the central region of the state (Borborema highlands), which are virtually unsurveyed. Although the recent increase of studies on bats in the state, future studies should complement conventional mistnetting with active roost search and bioacoustical records in order to obtain better data for unraveling the bat fauna of Rio Grande do Norte.
\end{abstract}

Keywords: Atlantic Forest, Caatinga, Chiroptera, Species distribution, Vulnerable species.

\section{Morcegos do estado do Rio Grande do Norte, nordeste do Brasil}

Resumo: O Rio Grande do Norte é um dos menores estados do Brasil, mas possui grande diversidade de ecossistemas, incluindo vegetação de Caatinga, Mata Atlântica, habitats costeiros, manguezais e grandes áreas cársticas com cavernas. No entanto, a fauna de quirópteros é pouco conhecida, e o estado contém lacunas importantes sobre a ocorrência e distribuição de morcegos no Brasil. Para reduzir essa lacuna de informação, com base em uma revisão da literatura científica e coleções regionais de mamíferos, listamos 42 espécies de morcegos, incluindo novas ocorrências para 13 espécies e discusões sobre seu estado de conservação. Os resultados mostram que mais de metade (54\%) das espécies registradas são morcegos filostomídeos e cerca de um terço dos morcegos no estado se abrigam em cavidades subterrâneas. A Caatinga abrigou a maior riqueza de morcegos no estado, incluindo a ocorrência de quatro espécies vulneráveis (Furipterus horrens, Lonchorhina aurita, Natalus macrourus e Xeronycteris vieirai). A Mata Atlântica precisa ser mais amostradas, incluindo manguezais, habitats costeiros e áreas de Caatinga principalmente na região central do estado (planalto da Borborema), que são virtualmente inexplorados. Embora o recente aumento das investigações no estado em relação aos morcegos, estudos futuros devem complementar os métodos convencionais de captura com procura ativa de abrigos e monitoramento bioacústico para obter melhores dados na tarefa de desvendar a diversidade de morcegos do Rio Grande do Norte.

Palavras-chave: Caatinga, Chiroptera, Espécies vulneráveis, Distribuição de espécies, Mata Atlântica. 


\section{Introduction}

About one-quarter of the Brazilian mammal species are bats (Paglia et al. 2012), currently comprising 183 known species (Nogueira et al. 2014, Feijó et al. 2015a, Fischer et al. 2015, Moratelli \& Dias 2015, Gregorin et al. 2016, Rocha et al. 2016). Considering that Brazil harbors one of the largest mammal diversities in the world, its bat fauna is poorly known. Bat records indicate that less than $10 \%$ of the Brazilian territory can be considered minimally sampled, and about $60 \%$ has no single formal record of bat species (Bernard et al. 2011).

The state of Rio Grande do Norte (RN) represents a conspicuous gap of bat information in Brazil (Bernard et al. 2011). The earliest records of bats in RN date back to the past century, when Sanborn (1937), Goodwin (1959), Webster (1993), and Jones \& Hood (1993) reported few bat records from the coastal region of the state (municipality of Natal) and deposited the specimens in biological collections in United States. Studies on bats in RN slowly began to increase in this century, with new records and distributional expansions (Feijó \& Nunes 2010, Barros 2014, Basílio et al. 2017), ecology and natural history (Cordero-Schmidt et al. 2016, Cordero-Schmidt et al. 2017), community diversity (Barros et al. 2017, Vargas-Mena et al. in press), and subterranean fauna inventories (Ferreira et al. 2010); including a bilbliographic review on the bat fauna in northeastern Brazil by Garcia et al. (2014). Such studies together have recorded a richness of 38 species of bats in the state.

Despite the recent efforts in describing the bat fauna of $\mathrm{RN}$, there are still gaps of knowledge. In addition, bat diversity and species distribution are poorly known in the state, and it is important for conservation strategies and policies (Costa et al. 2005). Therefore, we present an updated list of bat species based on available mammal collections and literature review in order to describe the bat species composition, distribution and richness that occur within the state's political boundaries and discuss conservation concerns based on the available data. We expect that this study will inform the scientific community, government agencies, non-governmental organizations, and general society about the diversity of bats that occurr in RN; will point out sites that need increased research efforts; and will be a reference baseline for ecological and diversity assessments, including those for environmental impact studies, to be carried out in the state.

\section{Material and Methods}

\section{Study Site}

The state of Rio Grande do Norte $(\mathrm{RN})$ is located in the northeastern region of Brazil between the latitudes $4^{\circ} 49^{\prime} 53$ ' $\mathrm{S}$ and $6^{\circ} 58^{\prime} 57^{\prime \prime} \mathrm{S}$ and longitudes $35^{\circ} 58^{\prime} 03^{\prime \prime} \mathrm{W}$ and $38^{\circ} 36^{\prime} 12^{\prime}$ 'W. It is limited to the north and the east by the Atlantic Ocean; to the west by the Ceará State, and the south with the state of Paraíba. RN has a territorial extension of 52,797 $\mathrm{km}^{2}$ and is composed of 167 municipalities, being one of the smallest states in Brazil (IDEMA 2015).

The $95 \%$ of the state is characterized by a semiarid climate where the Caatinga domain occurs (IDEMA 2015). According to Köppen classification, the climate in this portion of the state is BShw (hot and dry), with a mean annual rainfall of less than $800 \mathrm{~mm}$ (Alvares et al., 2013). The Caatinga is a seasonally dry tropical forest composed by mosaics of xeric spiny shrub lands, columnar cacti, succulents, and deciduous woody forest stands (arboreal caatingas) (Leal et al. 2003). Physiognomy and plant composition variations determine eight different ecoregions in the Caatinga; however, only two occur in RN: the Northern Sertaneja Depression (NSD) and the Borborema Highlands (BH) (see Velloso et al. 2002). The NSD is characterized by extensive low plains, with elevations varying from $20-500$ meters. The vegetation type is spiny shrub lands with herbaceous plants and remnants of arboreal Caatinga on slopes and low mountain ranges, and on the main river valleys there are ciliary remnants of Carnaúba palms (Copernicia prunifera). The $\mathrm{BH}$ ecoregion is mountainous with steep slopes and rugged relief, with rocky outcrops of granite. The altitude varies from $150-650 \mathrm{~m}$ and the vegetation is characterized by a shrubby-arboreal Caatinga with columnar cacti and arboreal Caatingas in more humid areas on the tops of the mountains.

On the east coast of the state, according to Köppen classification, the climate type is Aw with precipitations varying from 700-1500 mm (Alvares et al., 2013). This region harbors the northernmost distribution of the Atlantic Forest in Brazil (IDEMA2015). The RN's Atlantic Forest is composed of remnants of evergreen and semi-evergreen forests stands, dunes, short bushy-forests on fixed dunes (known as "restingas"), and mangroves (INPE/SOS Mata Atlântica 2014). Ecotones occur in contact areas of Caatinga and Atlantic Forest.

Finally, RN contains an important speleological heritage with the occurrence of extensive calcareous outcrops or "lajedos" that harbors numerous caves. Most caves occur in the northern and western region of the state in the Caatinga (Cruz et al. 2010), with the majority of caves located in the NSD ecoregion. RN has the fourth highest number of underground cavities in Brazil with more than 1000 recorded caves (Bento et al. 2017).

\section{Data collection}

To find bat records within the political boundaries of $\mathrm{RN}$, we searched in regional mammal collections (as primary data) and specialized bibliographic reviews (as secondary data). Primary data consisted of bat records in the mammal collections of the Universidade Federal de Pernambuco (UFPE) and the Universidade Federal of Rio Grande do Norte (UFRN) (Coleção Mastozoológica Adalberto Varela, CMAV). We only considered specimens with voucher number and location (geographic coordinates and municipality). We examined all bat specimens $(\mathrm{N}=166)$ currently deposited at CMAV (except one specimen without specific collection site data), and all bat specimens deposited at UFPE $(\mathrm{N}=128)$ that where collected in $\mathrm{RN}$. The species were identified using taxonomic keys of Neotropical bats, such as Simmons (1996), Gardner (2008), Gregorin \& Taddei (2002) and Díaz et al. (2016), as well as the original description of species on scientific articles. Specimens with doubtful identifications were confirmed by experts.

Secondary data were obtained from academic online databases (Google Scholar, Periódicos Capes, ScieELO, Science Direct, and Web of Science) using "Atlantic Forest", "bat", "Caatinga", "Chiroptera", "Mata Atlântica", "morcego", "quiróptero", and "Rio Grande do Norte" as keywords. Also, we consulted books and book chapters that deal with the subject. We compiled all the information available about bats in the state of $\mathrm{RN}$ and then selected only records originally published in peer-reviewed literature and books. Among the bat records from peer-reviewed literature and books, we selected only those supported 
by voucher specimens deposited in public scientific collections. Only the records that met both requirements (publication in peer-reviewed literature/books and availability of vouchers) were included in our list. However, all the bat records found in $\mathrm{RN}$, regardless of presence of voucher specimens, are included in the Supplementary Material.

The species nomenclature and taxonomic arrangement followed Nogueira et al. (2014) and Phyllostomidae species followed Baker et al. (2016). We recognized Lonchophylla inexpectata Moratelli \& Dias, 2015 as a different species from Lonchophylla mordax Thomas, 1903 (see Moratelli \& Dias 2015). Finally, we assigned for each species its current international and national conservation status following the IUCN Red List of Threatened Species (IUCN 2016) and Brazil Red Book of Threatened Species of Fauna (ICMBio/MMA 2016) respectively; its region (Caatinga and Atlantic Forest) of occurrence; locality(ies) of record(s); literature reference(s) and/or collection number(s) when available.

\section{Results}

We found 75 published records, of which 38 satisfied our criteria (peer-reviewed literature/books with voucher specimens), plus 66 unpublished records (CMAV and UFPE collections), totalizing 104 bat records included in the final species list (Table 1) from 141 bat records inspected (Table S1, Supplementary Material). We found records of 50 bat species among the 141 records (Supplementary Materials) and just 42 species according to our criteria for inclusion in the $\mathrm{RN}$ list (Table 1). These 42 species represented eight families: Phyllostomidae (23 species), Molossidae (6), Vespertilionidae (5), Emballonuridae (3), Noctilionidae (2), Furipteridae (1), Mormoopidae (1), and Natalidae (1). Eight species cited in the literature did not entered in the official list due to absence of voucher specimens, Peropteryx kappleri Peters, 1867; Saccopteryx canescens Thomas, 1901; S. leptura Thomas, 1901; Anoura caudifer (É. Geoffroy, 1818); Artibeus fimbriatus Gray, 1838; Chiroderma villosum Peters, 1860; Myotis riparius Handley 1960 and M. simus Thomas, 1901.

Records were reported in 21 localities, 18 in the Caatinga and three in the Atlantic Forest (Figure 1). All localities in the Caatinga corresponded to the NSD, with no records for the BH. The state's Caatinga presented an accumulated richness of 32 bat species whereas the Atlantic Forest did 22 species. Nineteen species were exclusive to the Caatinga and nine to the Atlantic Forest (Table 1). The species with the highest number of collected specimens (with voucher numbers) were Myotis lavali (31 specimens), Pteronotus gymnonotus (30), Molossus molossus (28), Artibeus planirostris (26), and Glossophaga soricina (22). The species found in more than one locality were G. soricina (eight localities), Peropteryx macrotis (seven), Myotis lavali (six); and Desmodus rotundus, Carollia perspicillata, and Molossus molossus (four) (Table 1).

Regarding the conservation status, 31 species are categorized as Least Concern (LC), three as Data Deficient (DD), two as Not Evaluated (NE), and only Natalus macrourus is regarded as Near Threatened (NT) in the IUCN Red List of Threatened Species (IUCN 2016). In the Brazil Red Book of Threatened Species of Fauna (ICMBio/MMA 2016), 34 species are regarded as LC, two as DD, two as NE, and four species are considered Vulnerable (VU), Furipterus horrens, Lonchorhina aurita, Natalus macrourus and Xeronycteris vieira (Table 1).
Of the 42 species of bats presented herein, 13 are new records for $\mathrm{RN}$ which are listed below.

\section{Family Emballonuridae Gervais, 1856}

Rhynchonycteris naso (Wied-Neuwied, 1820)

The only known records of this species in the state are two specimens collected close to water in the Poço Branco dam (5³7'48.96" $\mathrm{S}, 35^{\circ} 39^{\prime} 8.31^{\prime \prime} \mathrm{W}$ ) at $65 \mathrm{~m}$ a.s.l. on 16 November 1990 in a transition area between the Atlantic Forest and Caatinga. Specimens presented pointed and elongated snout, two light and weak stripes on back and forearms (35.9-37.8 $\mathrm{mm}$ ) with whitish tufts. Specimens are deposited in CMAV. Specimens examined: CMAV 105, 106.

\section{Family Phyllostomidae Gray, 1825}

Subfamily Micronycterinae

Micronycteris megalotis (Gray, 1842)

One specimen collected in a small calcareous outcrop surrounded by scrubby Caatinga vegetation close to the Porco do Mato cave in the Furna Feia National Park, Mossoró-Baraúna municipalities 5³'24.13" $\mathrm{S}, 37^{\circ} 30^{\prime} 54.03$ ' W) at $131 \mathrm{~m}$ a.s.l. It presented notch in ear band shallow; similar ventral and dorsal fur coloration; calcar longer than foot; and length of hair on the inner edge of the ear $>4 \mathrm{~mm}$. Specimen examined: CMAV 134.

\section{Micronycteris schmidtorum Sanborn, 1935}

Known from only one locality in Sítio Santa Rosa in Lajes municipality, where two individuals were captured in a riparian Caatinga close to a water dam $\left(05^{\circ} 49^{\prime} 56.2^{\prime} \mathrm{S}, 36^{\circ} 12^{\prime} 16.0^{\prime} \mathrm{W}\right)$ at $295 \mathrm{~m}$ a.s.1. Both specimens presented ventral fur very pale gray to almost white and calcar (10.2-10.4mm) longer than the foot $(6.5-8.5 \mathrm{~mm})$ which differentiates it from other Micronycteris bats with pale ventral fur (Fig 2A). Specimens examined: CMVA 140, 145.

\section{Micronycteris sanborni Simmons, 1996}

Only one recorded site in the Seridó Ecological Station in Serra Negra do Norte municipality $\left(6^{\circ} 34^{\prime} 55.4^{\prime}\right.$ ' S, 37 $\left.7^{\circ} 15^{\prime} 9.91^{\prime \prime} \mathrm{W}\right)$ at 200 $\mathrm{m}$ a.s.l. One adult male, and two females were collected at the edge of a natural lake in Caatinga vegetation. Specimens presented diagnostic characteristics of M. sanborni: gap between 12 and canine, length of calcar similar or shorter $(6.6-8.0 \mathrm{~mm})$ than foot $(7.6-8.1 \mathrm{~mm})$, thumb shorter than $7.5 \mathrm{~mm}(6.8-7.7 \mathrm{~mm})$ and pure white color in ventral fur (Fig 2B). Specimens examined: UFPE 3436, 3439, 3440.

\section{Subfamily Glossophaginae}

Anoura geoffroyi Gray, 1838

One male collected in Sítio Joazeiro at $230 \mathrm{~m}$ above sea level (a.s.l.) at the foothill of the Serra do Feiticeiro in a semi-open area with patches of scrubby caatinga vegetation, cacti, and some woody trees in Lajes municipality ( $05^{\circ} 45^{\prime} 55.7^{\prime}$ 'S, $\left.36^{\circ} 12^{\prime} 55.7^{\prime \prime} \mathrm{W}\right)$. The specimen presented diagnostic characteristics of $A$. geoffroyi with no lower incisors, short semicircular uropatagium, and forearm length of $40.2 \mathrm{~mm}$. (A. caudifer has forearm of 34-39mm). Specimens examined: CMAV 144.

Subfamily Lonchophyllinae

Lonchophylla inexpectata Moratelli \& Dias, 2015 
Vargas-Mena, J.C. et al.

Table 1. List of bat species recorded in the state of Rio Grande do Norte, northeastern Brazil, including conservation status according to International Union for Conservation of Nature (IUCN) and Brazilian Ministry of Environment (Ministério do Meio Ambiente, MMA), localities, voucher numbers and references of original records. Conservation status: LC - Least Concern; DD - Data Deficient; NE - Not Evaluated; NT - Near Threatened, and VU - Vulnerable. Regions are Atlantic Forest (AF) and Caatinga (CA). Localities are: Natal (1), Macaíba (2), Maxaranguape (3), Ceará-Mirim (4), Taipu (5), João Câmara (6), Guamaré (7), Galinhos (8), Jandaíra (9), Nísia Floresta National Forest, Nísia Floresta (10), Lagoa Salgada (11), Nova Cruz (12), Poço Branco (13), Lajes (14), Seridó Ecological Station, Serra Negra do Norte (15), Mossoró (16), Furna Feia National Park, Baraúna/Mossoró (17), Governador Dix-Sept Rosado (18), Felipe Guerra (19), Caraúbas (20), and Martins (21); coordinates are found in Fig. 1. Voucher specimens presented in collection number column correspond to the oldest specimen recorded in each locality. All collection numbers of revised specimens are found in Supplementary table. References in the original record column corresponds to the study who first recorded the species in the state. Collections abbreviations: CAS - California Academy of Science; CMAV - Coleção de Mamíferos Adalberto Varela, Universidade Federal do Rio Grande do Norte; CMUFS - Coleção de Mamíferos da Universidade Federal de Sergipe; MZUSP - Museu de Zoologia da Universidade de São Paulo; UFPB - Coleção de Mamíferos da Universidade Federal da Paraíba; UFPE - Coleção de Mamíferos da Universidade Federal de Pernambuco; USNM - United States National Museum. New species records are indicated with an asterisk $(*)$.

\begin{tabular}{llllll}
\hline Family/Subfamily/Species & IUCN/MMA & Region & Localities & Collection number Original record
\end{tabular}

Emballonurinae

Peropteryx leucoptera Peters, 1867

Peropteryx macrotis (Wagner, 1843)
LC

$\mathrm{LC}$ AF CA

Collection number

\section{Emballonuridae Gervais, 1856}

LC

LC

$\mathrm{X}$
$\mathrm{X}$

X

10
$, 9,13,14$
$18,19,20$

UFPE 3193

Barros et al. 2017

$18,19,20$

USNM (not informed),

CMAV 111, CMAV

107, CMAV 122,

CMAV 130, CMAV

Sanborn 1937;

Vargas-Mena et al.

129, CMAV 131

Rhynchonycteris naso (Wied-Neuwied, 1820)*

LC

X

13

CMAV 105

This study

Phyllostomidae Gray, 1825

Micronycterinae

Micronycteris megalotis (Gray, 1842) *

LC

Micronycteris schmidtorum Sanborn, 1935*

Micronycteris sanborni Simmons, 1996*

Desmodontinae

Desmodus rotundus (É. Geoffroy, 1810)

Diphylla ecaudata Spix, 1823

Lonchorhininae

Lonchorhina aurita Tomes, 1863

Phyllostominae

Chrotopterus auritus (Peters, 1856)

Lophostoma brasiliense Peters, 1866

Phyllostomus discolor (Wagner, 1843)

Phyllostomus hastatus (Pallas, 1767)

Tonatia bidens (Spix, 1823)

Trachops cirrhosus (Spix, 1823)

Glossophaginae
Anoura geoffroyi Gray, 1838*

Glossophaga soricina (Pallas, 1766)

LC

LC $\quad \mathrm{X} \quad \mathrm{X}$

14

$1,4,5,10$,

$12,14,15$,

16

CMAV 144

CAS (not informed number), CMAV 015, CMAV 061, UFPE 3257, CMAV 002, CMAV 124, UFPE 3423, CMAV 147

Lonchophyllinae

Lonchophylla mordax Thomas, 1903*

Lonchophylla inexpectata Moratelli \& Dias, 2015*

Xeronycteris vieirai Gregorin \& Ditchfield, 2005

$\begin{array}{cccl}\text { NT / LC } & \mathrm{X} & 15,16 & \begin{array}{l}\text { CMAV 149, UFPE } \\ 3424,\end{array} \\ \text { NE } & \mathrm{X} & 14 & \text { CMAV 167 } \\ \text { DD/VU } & \mathrm{X} & 14 & \text { CMAV 143 }\end{array}$

This study
This study
This study

Barros et al. 2017; This study

Vargas-Mena et al. in press

Vargas-Mena et al. in press

Basílio et al. 2017

Barros et al. 2017

Barros et al. 2017; This

study

Barros et al. 2017

Vargas-Mena et al. in press

Barros et al. 2017; This

study

This study

Barros et al. 2017; Vargas-

Mena et al. in press;

Webster 1993; This study

Vargas-Mena et al. in press This study

This study

Cordero-Schmidt et al. 2017 
Continued Table 1.

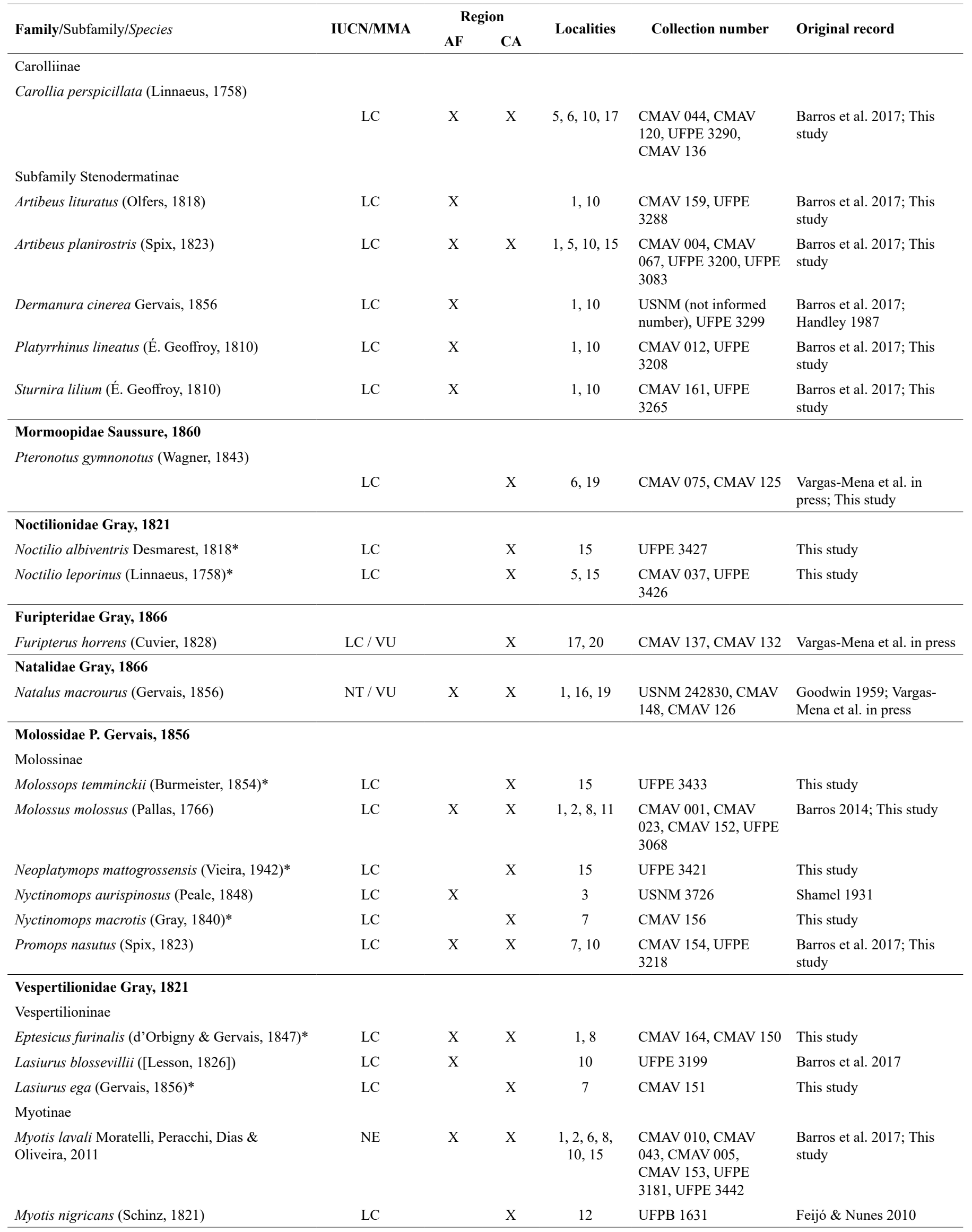




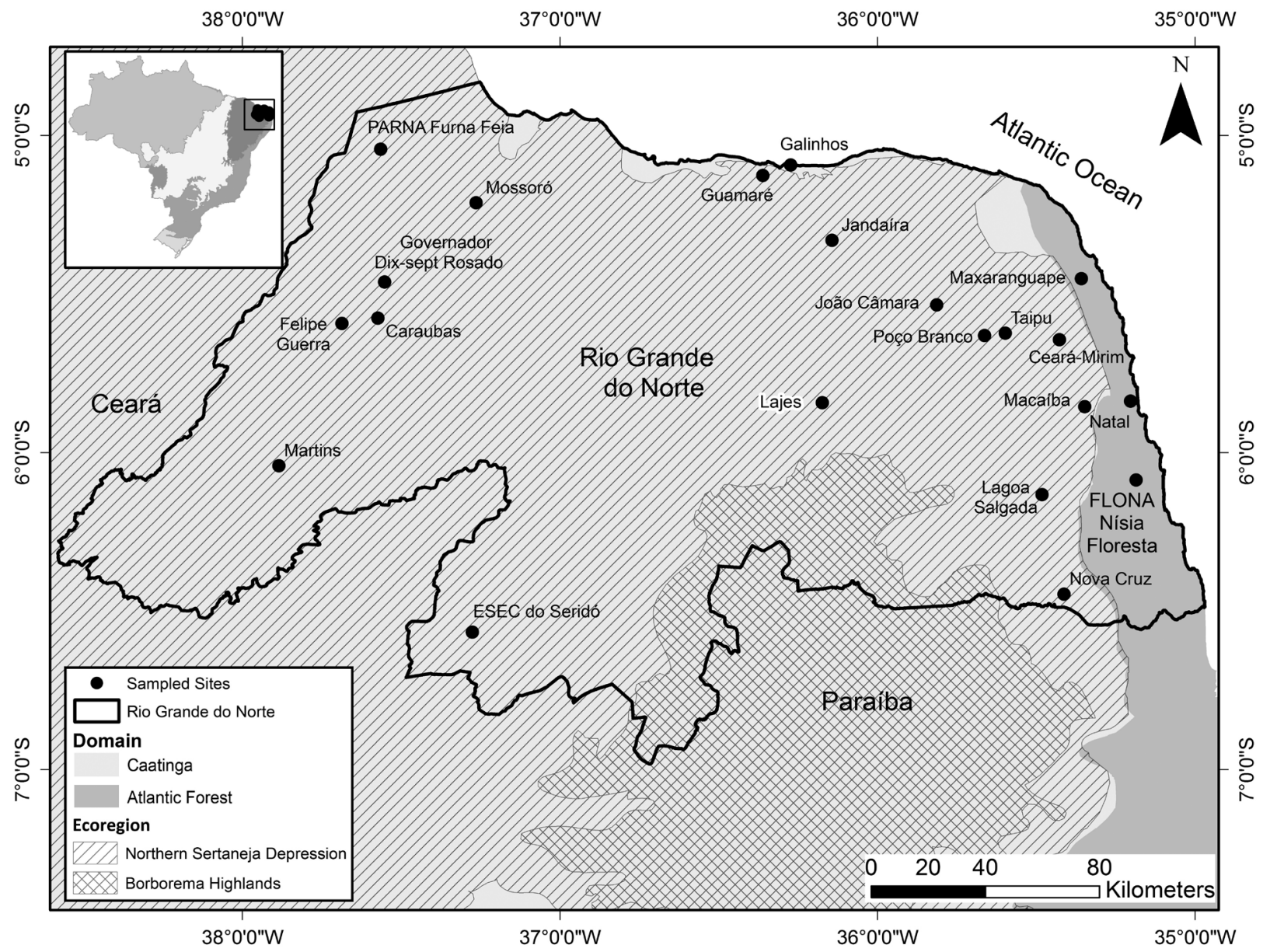

Figure 1. Map showing site localities where at least one bat has been sampled within the state of Rio Grande do Norte, northeastern Brazil. Coordinates

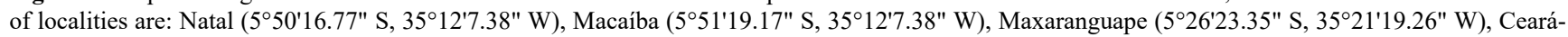

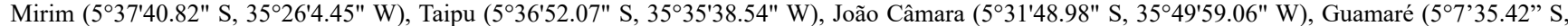

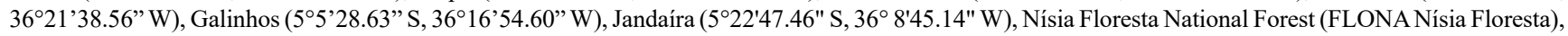

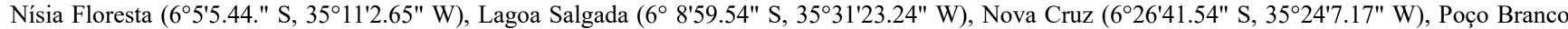

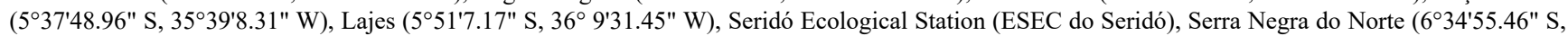

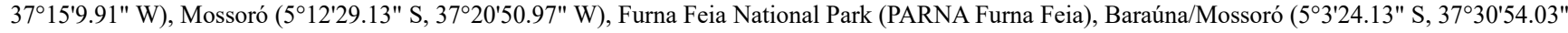

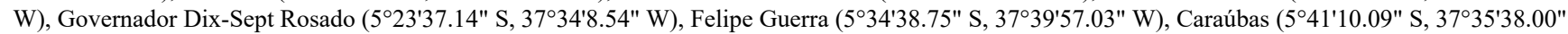
W), and Martins (6 $\left.2^{\prime} 54.68^{\prime \prime} \mathrm{S}, 37^{\circ} 53^{\prime} 43.99^{\prime \prime} \mathrm{W}\right)$.

This recently described species was recorded only at the Serra do Feticeiro in Lajes municipality (5'51'7.1'S, 369'31.4'W) at 325 $\mathrm{m}$ a.s.l. Six specimens were collected and identified as L. inexpectata by their pale-greyish ventral fur on the throat and abdomen that differs from $L$. mordax which has pale-brownish ventral fur as indicated by Moratelli \& Dias (2015) (Fig 3A). Specimens examined: CMAV 121, 123, 141, 142, 146, 167.

\section{Family Noctilionidae Gray, 1821}

\section{Noctilio albiventris Desmarest, 1818}

One adult female collected in the Seridó Ecological Station, Serra Negra do Norte on the edge of a natural lake (6 $34^{\prime} 55.4^{\prime}$ 'S, 37¹5'9.91" $\mathrm{W})$ at $200 \mathrm{~m}$ a.s.l. We also captured an adult in Sítio Santa Rosa, Lajes municipality $\left(05^{\circ} 49^{\prime} 56.2^{\prime \prime} \mathrm{S}, 36^{\circ} 12^{\prime} 16.0^{\prime \prime} \mathrm{W}\right)$ in a drying water reservoir on 10 May 2015, but only biometrical data and photographs data were taken. Specimens presented forearm length less than $70 \mathrm{~mm}(55.7 \mathrm{~mm})$ which differentiates it from the similar but larger N. leporinus (FA: $>70$ $\mathrm{mm})$ Specimens examined: UFPE 3427.

Noctilio leporinus (Linnaeus, 1758)

Collected only in two localities of Caatinga. The first record is of an adult male collected and deposited in CMAV on 17 January 1990 in Taipu municipality $\left(5^{\circ} 36^{\prime} 52.07^{\prime}\right.$ ' $\left.\mathrm{S}, 35^{\circ} 35^{\prime} 38.54^{\prime \prime} \mathrm{W}\right)$ in an ecotone area close to the BR-404 highway with no habitat specification at $30 \mathrm{~m}$ of altitude. The second record corresponds to an adult male captured near a lake (6³4'55.4" S, 37² $15^{\prime} 9.91$ " W) on 18 July 2012 in the Seridó Ecological Station, Serra Negra do Norte municipality at $200 \mathrm{~m}$ a.s.l. The specimens presented diagnostic characteristics of $N$. leporinus, forearm length of $>70 \mathrm{~mm}(82.5-85.4 \mathrm{~mm})$ and legs length exceeding head length that differentiates it from the smaller $N$. albiventris. Specimens examined: CMAV 037; UFPE 3426. 


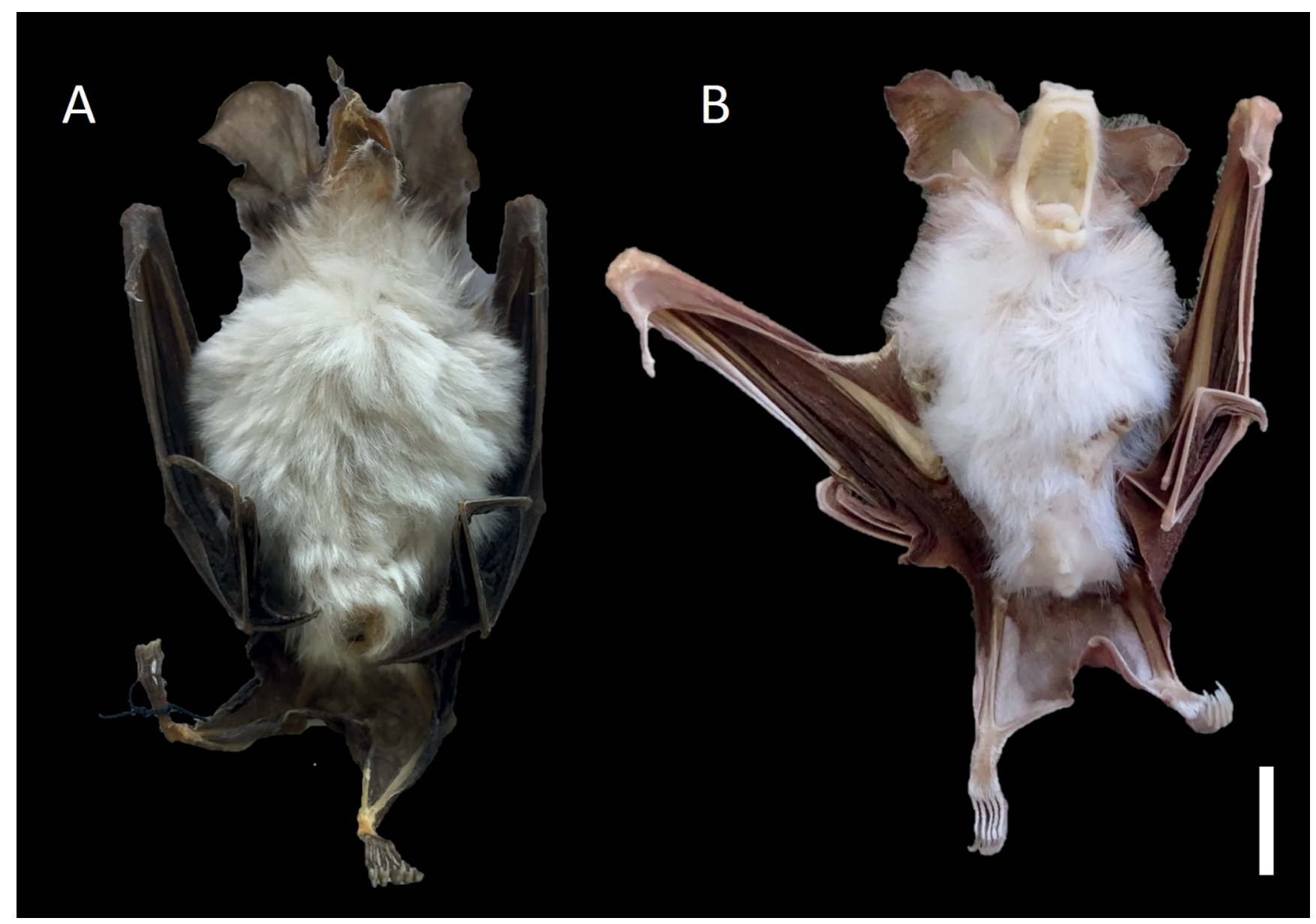

Figure 2. Ventral pelage of A Micronycteris schmidtorum (CMAV 145) and B Micronycteris sanborni (UFPE 3440). Note very pale gray almost white color of the ventral fur of A that differs from pure white color of B. Lengths of foots, calcars and thumbs of A and B are found in results. Scale bar $10 \mathrm{~mm}$.

\section{Family Molossidae Gervais, 1856}

Molossops temminckii (Burmeister, 1854)

One adult female captured on 9 March 2013 in an semi-open area in the Seridó Ecological Station (6³4'55.4” S, 37¹5'9.91” W) at 200 $\mathrm{m}$ a.s.l. It presented triangular ears, semi-squared antitragus and forearm less than $34 \mathrm{~mm}$ (30.2 mm), which differentiates it from its congener in Brazil (M. neglectus) that has a forearm greater than $36 \mathrm{~mm}$. Specimen examined: UFPE 3433.

\section{Neoplatymops mattogrossensis (Vieira, 1942)}

This molossid bat has been captured only in the Seridó Ecological Station in open areas near a natural lake $\left(6^{\circ} 34^{\prime} 55.4^{\prime \prime} \mathrm{S}, 37^{\circ} 15^{\prime} 9.91^{\prime \prime}\right.$ W) at $200 \mathrm{~m}$ a.s.l. All six captured specimens presented flattened head, upper incisors separated by a space and granulations or small protrusion in forearms; these characteristics separate $N$. mattogrossensis from other Neotropical small flat-headed molossids. Specimen examined: UFPE 3421, 3422, 3435, 3437, 3438, 3441.

\section{Nyctinomops macrotis (Gray, 1840)}

One adult female found dead on the ground at a wind farm in a coastal Caatinga in Guamaré municipality, north coast of the state (5 $7^{\circ} 35.42$ " S, 36² $1^{\prime} 38.56^{\prime}$ W) near sea level. The bat presented damages on head, neck and dorsal area probably caused by a direct collision with the turbine blades. The specimen presented deeply wrinkled lips; joined ears; incisors $1 / 2$, upper incisors parallel to each other; and forearm greater than $55 \mathrm{~mm}(\mathrm{FA}=58.2 \mathrm{~mm})$, characteristic that differentiates it from other smaller Nyctinomops bats in Brazil (FA $<55 \mathrm{~mm})$. Specimen examined: CMAV 156.

\section{Family Vespertilionidae Gray, 1821}

Eptesicus furinalis (d'Orbigny \& Gervais, 1847)

Two specimens collected in different localities. An adult male captured in a house roof in Galinhos municipality in the coastal Caatinga $\left(5^{\circ} 5^{\prime} 28.63\right.$ ' S, 36 $\left.16^{\prime} 54.60^{\prime \prime} \mathrm{W}\right)$ at sea level and another adult male captured in garden area on the campus of the Federal University of Rio Grande do Norte (5'50'16.77'S, 35'12'7.38'W), at 45 m.a.s.l. Despite specimens presented forearms lengths of $40.1-41.0 \mathrm{~mm}$ that overlaps with smaller individuals of $E$. brasiliensis (forearm length of E. furinalis $=37.0-41.0 \mathrm{~mm}$ and E. brasiliensis $=40-46 \mathrm{~mm}$ ), both presented characteristics of $E$. furinalis, narrow but not tapered tragus, short fur (5-6 mm), lower teeth row length less than $6.3 \mathrm{~mm}$, and skull length less than $16.3 \mathrm{~mm}$. Specimens examined: CMAV 150, 164.

\section{Lasiurus ega (Gervais, 1856)}

One adult male found dead at a wind farm in Guamaré municipality (57'35.42” S, 36 21'38.56" W) near sea level. The bat had damages on the head and dorsal region, probably caused by a collision with turbine blades; however, the skull suffered no damages. The specimen 


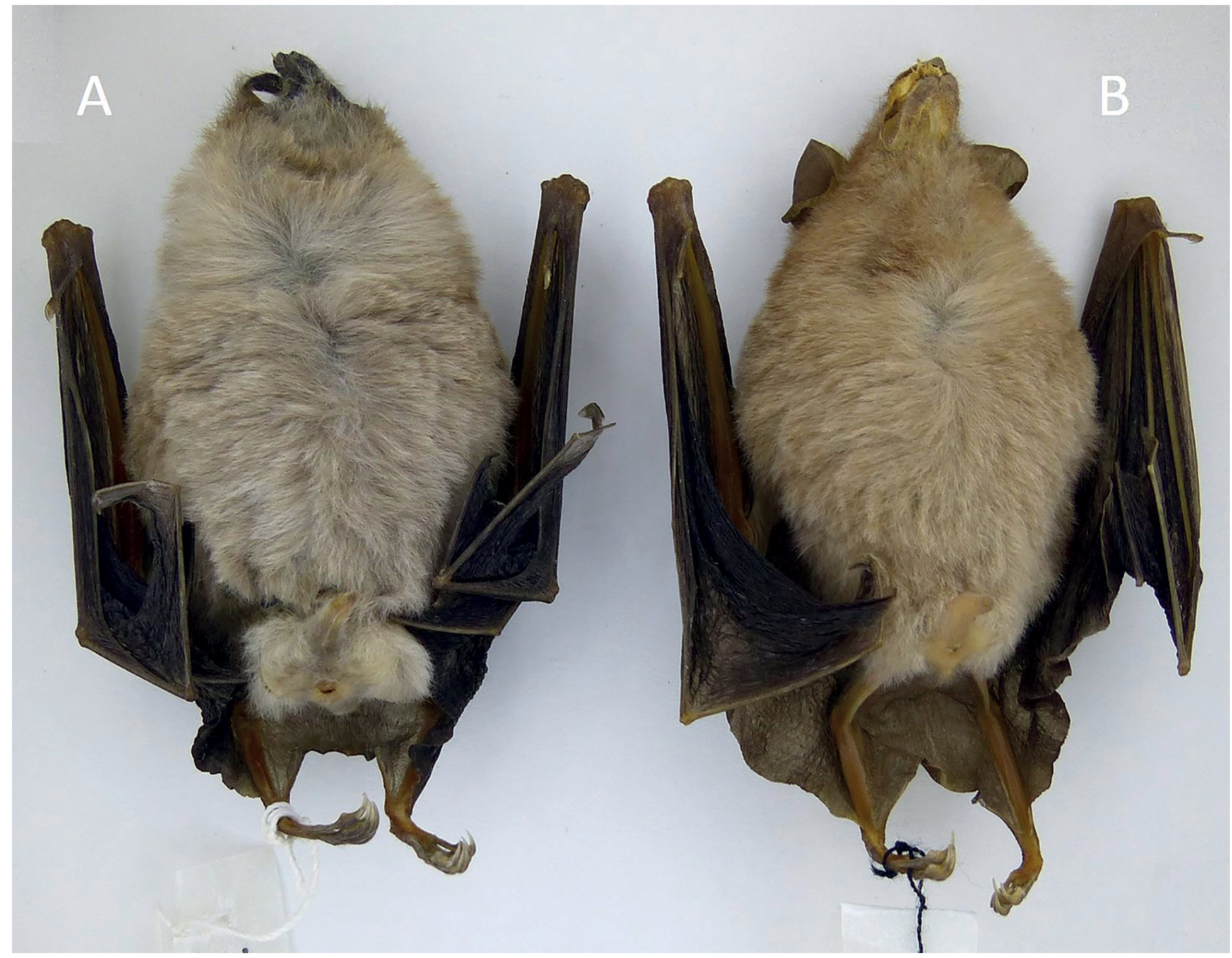

Figure 3. Ventral pelage of A Lonchophylla inexpectata (CMAV 167) and B Lonchophylla mordax (CMAV 149). Note the pale-greyish ventral fur on the throat and abdomen of A that differs from the pale-brownish ventral fur of B. Scale bar $10 \mathrm{~mm}$.

was identified as L. ega due to its olive-yellowish coloration in ventral and dorsal region; hairs covering down to the half of the uropatagium on the dorsal side; and single upper premolars. Specimen examined: CMAV 151.

\section{Discussion}

\section{Species richness}

The richness of bats in $\mathrm{RN}$ is greater than previously known. Of the 38 species of bats previously reported in RN (Feijó \& Nunes 2010, Ferreira et al. 2010, Barros 2014, Garcia et al. 2014, Cordero-Schmidt et al. 2016, Basílio et al. 2017, Cordero-Schmidt et al. 2017, Vargas-Mena et al. in press) we found vouchers for only 29 species. However, by adding the 13 new species records that we present herein, the number of species with confirmed occurrence in the state is 42 (Table 1).

Compared to the neighboring states of Ceará and Paraíba, RN presents a lower bat richness. The state of Paraíba, with a diversity of 58 species (Feijó \& Langguth 2011, Ferreira et al. 2013, Nunes et al. 2013, Leal et al. 2014, Beltrão et al. 2015, Vilar et al. 2015), is similar to RN in size and proportion of Caatinga and Atlantic Forest, however, it has been more sampled (Bernard et al. 2011). Similarly, the state of Ceará contains a richer bat diversity (66 species) (Gurgel-Filho et al. 2015, Silva et al. 2015), but its bat fauna has been more studied than for $\mathrm{RN}$, including the firsts surveys on Caatingas' mammal communities (e.g., Mares et al. 1981, 1985, Willig 1983).

The bat richness found in RNs' Caatinga was higher than in the states' Atlantic Forest, probably because of the lower number of collection sites in the latter (Fig 1). Since all of sites in Caatinga are in the NSD, our study contributes to fill the knowledge gap in this part of the ecoregion by adding 15 new localities of bat data collection in relation to the records reported by Carvalho-Neto et al. (2016). Previous authors, after reviewing the bat species richness in the Caatinga, warned that the eastern part of the NSD and the north of the BH have not been comprehensively investigated. Based on Velloso et al. (2002) ecoregions of Caatinga, our map (Fig. 1) does not show records in the Borborema Highlands, thus the bat fauna of the northern distribution of this ecoregion is poorly known.

Although the Atlantic Forest showed only three localities of bat collections, the richness difference with the Caatinga is not large - a difference of 10 species. Considering that the Atlantic Forest in Brazil is richer in bat species than the Caatinga (Paglia et al. 2012), it is likely 
that an increase in research in this region will yield a higher richness than what was found in this study.

Phyllostomid bats represented more than half of the species records (54\%). This proportion is similar to other Brazilian states, with the occurrence of Atlantic forest and Caatinga, like in Paraíba (Feijó \& Langguth 2011) and Sergipe (Leal et al. 2013). Such dominance was expected since Phyllostomidae is the richest family in Brazil (Nogueira et al. 2014) and in the Neotropics (Solari \& Martínez-Arias 2014).

Furthermore, all bat studies in RN were done using mist nets, a type of methodology heavily biased towards the capture of phyllostomids than species of other families (Barnett et al. 2006). Consequently, the diversity of aerial insectivorous bats, such as members of the Emballonuridae, Molossidae, and Vespertilionidae families, are poorly known in RN, probably because all of the studies conducted in RN used mainly mist-nets. Acoustic samplings (recordings of bat echolocation calls) detect aerial insectivores not sampled by conventional capture methods (Simmons \& Voss 1998) and, thus, this method should be used together with bat captures to increase inventory completeness (MacSwiney et al. 2008). Moreover, in Neotropical dry forests where nearly half of the species are open-space insectivores, Silva \& Bernard (2017) found that different bat species were detected using solely mist nets or bioacoustics, therefore authors conclude that a combination of both techniques is essential to achieve the local bat diversity in Caatinga areas.

The search for day roosts is another good alternative to increase the knowledge on bat species richness of the state. Caves are an important roost for local bat populations considering the high number of underground cavities that occur in RN. Inventories in such areas are likely to provide new species occurrences, and to contribute to a better understanding of the bat species distribution in the state. For instance, 17 species of bats have been already recorded to roost in RN's caves (Vargas-Mena et al. in press, Cordero-Schmidt et al. 2017), this is one-third of the total bat species presented herein.

The bat diversity in Brazil is still being discovered as recent taxonomic revisions of specimens in the biological collections have led to the description of new bat species. For instance, of these recently described species, Myotis lavali (Moratelli et al. 2011) and Lonchophylla inexpectata occur in RN. Myotis lavali was recently described from the Myotis nigricans (Schinz, 1821) complex after specimens' revision in biological collections. We revised M. nigricans specimens from CMAV and UFPE that occur in RN and all of them corresponded to M. lavali. The only record of M. nigricans in the state was provided by Feijó \& Nunes (2010) from Nova Cruz municipality, close to Paraíba state; however, we did not have access to the collected specimen to confirm the taxon. Similarly, L. inexpectata was described from L. mordax by Moratelli \& Dias (2015) after specimens' revision in biological collection, and is currently considered endemic to Caatinga.

The confirmation of the species that we found in the literature review without vouchered specimens is needed. Of those seven non-confirmed species, for Peropteryx kappleri we did not find any locality or record whatsoever, despite Garcia et al. (2014) record it in the state. The remaining six species were recorded by Farias (2009) (see Supplementary Material) in a small Atlantic Forest patch in the Jiquí Public Park in Parnamirim municipality. Considering the possible presence of these species in the state, we call the attention to future bat studies in the Atlantic Forest to collect and confirm their occurrence.

\section{New species records}

Here, we presented 13 bat species with no previous record in RN, which increases our knowledge on the occurrence and distribution of the chiropteran fauna of RN and Brazil. Species such as Rhynchonycteris naso, Micronycteris megalotis, M. sanborni, Anoura geoffroyi, Noctilio albiventris, N. leporinus, Molossops temminckii, Neoplatymops mattogrossensis, Eptesicus furinalis, and Lasiurus ega have been already recorded in the neighboring states of Paraíba (Feijó \& Langguth 2011) and Ceará (Gurguel-Filho et al. 2015), therefore, their occurrence was expected in $\mathrm{RN}$.

Two pale-bellied species of Micronycteris (M. schmidtorum and M. sanborni) were found to occur in the state (Fig. 2). Both records represent a northward expansion of the distribution of these species in Brazil. Micronycteris schmidtorum has a wide distribution in Brazil but records in the Caatinga are scarce (Rocha et al. 2017) and the closest locality is from Exu, Pernambuco State (Ascorra et al. 1991) - about $430 \mathrm{~km}$ from our record in Lajes. However, there is a closer record about $146 \mathrm{~km}$ southeast from Lajes in the Atlantic Forest in Guaribas Biological Reserve in Paraíba State (Rocha et al. 2017). M. sanborni is endemic to Brazil and known from 10 scattered localities (Feijó et al. 2015b). We only found it in the Seridó Biological Station and its closest previous record is from $42.6 \mathrm{~km}$ south in Patos in the Caatinga of Paraíba State (Feijó et al. 2015b). However, M. sanborni might be more common than previously thought because it is difficult to differentiate from other sympatric pale-bellied Micronycteris bats in Brazil. We encourage special attention when identifying this bat species to avoid misidentification and to better understand their distribution and habitat preferences.

The record of L. inexpectata in RN, specifically at the Serra do Feticeiro in Lajes, expands the distribution of the species northeastwards about $430 \mathrm{~km}$ from the closest record in Exu, Pernambuco State (Moratelli \& Dias 2015). This record is noteworthy since the species has been registered only in the states of Bahia and Pernambuco (Moratelli \& Dias 2015), where it is considered endemic to the Caatinga (Gutiérrez \& Marinho-Filho 2017). However, sympatry in certain areas of the Caatinga of L. inexpectata with L. mordax can be found $-L$. mordax occurs along the eastern border of the Caatinga and the Atlantic Forest-Caatinga ecotone. We found both species in sympatry in Lajes, however its differentiation in the field is fuzzy which difficult identification (R. Moratelli pers. comm.). Although these two species can be differentiated by mandibular length (MAL) and ventral fur color (VFC) (L. mordax, MAL 15.5-17.0 mm, VFC pale brown; L. inexpectata MAL 14.1-16.3 mm, VFC whitish or pale gray on neck and abdomen), the six analyzed specimens of Lonchophylla of Lajes presented overlapping MAL (15.4-16.2 mm). Therefore, external characters for differentiating these species were restricted to the VFC (Fig. 3).

Regarding Nyctinomops macrotis, the species has been recorded mainly in the Atlantic Forest but as well in other regions; in Caatinga it is known for just one locality (Rocha et al. 2015). However, the record of N. macrotis in Guamare expands the species distribution northeastward about $740 \mathrm{~km}$ from the closest record in Boqueirão da Onça in Bahia State (Rocha et al. 2015). This second record suggest that the species might occur in other areas of the Caatinga, thus, acoustic surveys should be done in order to detect this or other molossid bats in RN. 


\section{Conservation panorama}

Four threatened bat species in Brazil occur in $\mathrm{RN}$, corresponding to the $57 \%$ of the Brazilian threatened bat species (see ICMBio/MMA 2016). Furipterus horrens, Natalus macrourus, Lonchorhina aurita and Xeronycteris vieirai are vulnerable species (VU), a high extinction risk category (ICMBio/MMA 2016). Moreover, F. horrens and L. aurita roost mainly in caves (Reis et al. 2007), N. macrourus is cave-dependent (Tejedor \& Davalos 2016) and, X. vieirai, is only known to roost in caves (Cordero-Schmidt et al. 2017). Therefore, their conservation status is linked to their dependence on cave roosts (Sagot \& Chaverri 2015). Bats species that rely on a single roost type are linked to higher extinction risks, and management actions to preserve such species should prioritize the protection of roosting sites (e.g., cave-dependent species) (Sagot \& Chaverri 2015). Consequently, the possible presence of these species should be considered when biospeleological inventories and cave-use licensing are carried out in the states' caves.

On the other hand, according to the IUCN international criteria, all bats that occur in RN are at lower risk of extinction, where just $N$. macrourus and L. mordax are near threatened (NT). This categorization was different from what we found at national level. Such a mismatch between these assessments, where species are considered nationally but not globally threatened, represents cases of globally common and stable species that are rather rare or declining at a local or regional level (Brito et al. 2010). However, L. mordax, previously classified as least concern (LC), is categorized as NT because now its distribution is restricted to just in three localities in eastern Brazil as consequence of its separation with L. inexpectata (Sampaio et al. 2016). Regarding this latter species, the IUCN has not yet evaluated its conservation status in Brazil, and it was therefore not included in threatened species lists (Gutiérrez \& Marinho-Filho 2017). Given the endemic condition of $L$. inexpectata (Caatinga) and L. mordax (Eastern Brazil) their extinction risks should be assessed soon at the national and global level.

The evaluation of the distribution and analysis of pressures and threats to these vulnerable species is needed to assess their conservation needs. For instance, the vulnerable N. macrourus has already lost $54 \%$ of its habitat in Brazil, and only $4 \%$ of its potential distribution of the species is located within fully protected areas (Delgado-Jaramillo et al. 2017). In RN, only F. horrens and N. macrourus have populations integrally protected in the Furna Feia National Park in Baraúna and Mossoró municipalities (Vargas-Mena et al. in press), while $X$. vieirai and $L$. aurita occur in no protected areas.

The natural vegetation in RN has suffered substantial human impacts, only the $11 \%$ the state is under some protected area (Bento et al. 2013). The Atlantic Forest has been reduced by agricultural activities and urban expansion in coastal areas (INPE/SOS Mata Atlântica 2014), whereas Caatinga has suffered deforestation for human use and cattle activities that make it susceptible to desertification (Santos et al. 2011). Such human activities are already known to negatively affect the integrity of bat communities and their populations around the world (Furey \& Racey 2016). Furthermore, RN has currently 125 wind farms, being the largest producer of wind energy in Brazil (ABBEólica 2017). Wind turbine facilities can cause high mortality among aerial insectivore bats (Barros et al. 2015; Schuster et al. 2015; Hein \& Schirmacher 2016; O'Shea et al. 2016; Frick et al. 2017). Bat occurrences in the areas of wind farms, as well as the possible impacts of wind turbines on bats, are still unknown (Bernard et al. 2014). For instance, some of the new species records presented herein (e.g., N. macrotis and L. ega) are based on single specimens found dead probably by wind turbines in wind parks.

\section{Main knowledge gaps}

Although this study updates information regarding the bat fauna of $\mathrm{RN}$, several gaps of knowledge on the distribution of bat species still remains in the state (Fig 1). Therefore, we propose additional effort of research and inventories in the following areas:

- The Northern Sertaneja Depression: all records of bats in the states' Caatinga are in this ecoregion. According to the distribution of the bat records, however the central region presented the most evident gap, and bat inventories are encouraged in such area. Moreover, most of protected areas of the state are found in this ecoregion and the Seridó Ecological Station in Serra Negra do Norte, the Açu National Forest in Açu and the Furna Feia National Park in Mossoró-Baraúna are areas where the bat fauna is poorly known and should be priorities for inventories in the state.

- The Borborema Highlands and other mountainous ranges in the central and southwestern region: this mountain ranges (ranging from $400-800 \mathrm{~m}$ of altitude), characterized by more humid areas with Caatinga vegetations, are virtually unexplored regarding bats, and particular assemblages are expected to occur in these areas. For instance, in the Serra do Feticeiro in Lajes do Cabugi, all five species of nectar feeding bats registered in the state are found in this sierra, including endemic and vulnerable species such as Xeronycteris vieirai and Lonchophylla inexpectata (Cordero-Schmidt et al. 2017). Considering that no conservation units are found in $\mathrm{BH}$ and other mountainous ranges, the sierras in the municipalities of Serra de Santana, Cerro Corá, Coronel Ezequiel, São Tomé Martins, Portalegre, Serrinha dos Pintos, and Luís Gomes, should be explored.

- Transitional areas of Caatinga with mangroves and coastal habitats all along the north coast such as in the municipalities of Dunas do Rosado, Galinhos, and Caiçara do Norte are unique ecotones with no data regarding bats, including the State Sustainable Development Reserve (RDS) Ponta do Tubarão, in Macau and Guamaré municipalities.

- Ecotone areas alongside the contact of Caatinga and Atlantic Forest are known as "Agreste", where bat communities may contain a mixture of species of both ecoregions.

- The southeastern region where there are remnants of Atlantic Forest; some of them in protected areas such as Private Reserve of Natural Heritage Mata da Estrela, in Baía Formosa municipality (the largest Atlantic Forest patch of RN), the northern part of the Nísia Floresta National Forest, in Nísia Floresta municipality (Barros et al. 2017), the Environmental Protection Area (APA) Jenipabú in Natal and Extremoz municipalities, and the Dunas State Park in Natal, one of the biggest urban park in Brazil. 
- The Mangrove in the east and north coast are also unexplored.

- Finally, the karstic areas located in Mossoró, Baraúna, Felipe Guerra, Apodi, Governador Dix-Sept Rosado, and Jandaíra municipalities are sites with high density of underground cavities and potential sites to roost a wide diversity of bats. For instance, the Furna Feia cave located in the Furna Feia National Park harbors up to 10 species, the richest in the state (Vargas-Mena et al. in press).

Despite the small size of $\mathrm{RN}$, the state has a potential to be an important refuge for bat diversity in northeastern Brazil, as long as bat inventories and specimens' collection increases in the future. Finally, bat inventories, including those for environmental impact studies, should complement conventional capture methods with bioacoustical monitoring and active searching of roost places to obtain a complete understanding of the bat fauna of Rio Grande do Norte.

\section{Supplementary material}

The following online material is available for this article:

Table S1 - List of bat records (Mammalia, Chiroptera) in the state of Rio Grande do Norte, northeastern Brazil, based on review of literature and specimens in collections. Abbreviations: CAS - California Academy of Science; CMAV - Coleção de Mamíferos Adalberto Varela, Universidade Federal do Rio Grande do Norte; CMUFS - Coleção de Mamíferos da Universidade Federal de Sergipe; MZUSP - Museu de Zoologia da Universidade de São Paulo; UFPB - Coleção de Mamíferos da Universidade Federal da Paraíba; UFPE - Coleção de Mamíferos da Universidade Federal de Pernambuco; USNM - United States National Museum.

\section{Acknowledgments}

We thanks to National Council for Scientific and Technological Development (CNPq) for research grants (Pesquisador Visitante Especial-PVE Project: 401467/2014-7; and CNPq/ICMBio 13/2011 - Project 552006/2011-4; to the Coordenação de Aperfeiçoamento de Pessoal de Nível Superior (CAPES) for the post-graduation scholarship to JCVM, KAP, MASB, EB and ECS; and CNPq for the productivity grant (309458/2013-7) to EMV. To Wildlife Conservation Society (WCS) Brazil for the logistical support. We are very grateful to Enrico Bernard for providing data of the Seridó Ecological Station; to Francisco Sagot-Martin for donating specimens from the municipality of Guamaré to CMAV; to Edson Leal for providing bibliographic material; to Ricardo Moratelli and Daniela Dias for the discussions and identification of Lonchophylla bats; to Cynthia Christina Ito for the photos of some specimens; to Diego Astúa for allowing the access to the collection; and to Christina M. Smith for English revision of the manuscript. We dedicate this paper to Prof. Adalberto Antônio Varela Freire (in memorian) for his pioneering work in collecting bats of Rio Grande do Norte, which provided most of the material recently organized in the mastozoological collection of the Federal University of Rio Grande do Norte, named - Coleção Mastozoológica Adalberto Varela.

\section{Author Contributions}

Juan Carlos Vargas-Mena: contributed with the concept and design of the study and manuscript preparation;

Kleytone Alves-Pereira, Marília Abero Sá Barros, Eder Barbier, Eugenia Cordero-Schmidt: contributed with data collection, analysis and interpretation;

Sergio Maia Queiroz Lima, Bernal Rodríguez-Herrera, Eduardo Martins Venticinque: contributed with analysis, interpretation and critical revision.

\section{Conflicts of interest}

The authors declare that they have no conflict of interest related to the publication of this manuscript.

\section{References}

ABBEÓLICA. 2017. Dados Mensais da Associação Brasileira de Energia Eólica - Abril de 2017. São Paulo, ABEEólica. Available in: http://www.abeeolica org.br/wp-content/uploads/2017/04/Dados-Mensais-ABEEolica-04.2017. pdf

ALVARES, C.A., STAPE, J.L., SENTELHAS, P.C., DE MORAES, G., LEONARDO, J. \& SPAROVEK, G. 2013. Köppen's climate classification map for Brazil. Meteorol. Z. 22(6), 711-728.

ASCORRA, C. F., WILSON, D. E., \& GARDNER, A. L. 1991. Geographic distribution of Micronycteris schmidtorum sanborn (Chiroptera: phyllostomidae). P. Biol. Soc. Wash. 104(2):351-355.

BAKER, R.J., SOLARI, S., CIRRANELLO, A. \& SIMMONS, N. B. 2016. Higher level classification of phyllostomid bats with a summary of DNA synapomorphies. Acta Chiropterol. 18(1):1-38.

BARNETT, A.A., SAMPAIO, E.M., KALKO, E.K.V., SHAPLEY, R.L., FISCHER, E., CAMARGO, G. \& RODRÍGUEZ-HERRERA, B. 2006. Bats of Jaú National Park, central Amazonia, Brazil. Acta Chiropterol. 8: 103-128.

BARROS, M.A.S. 2014. First record of Molossus molossus (Pallas, 1766) (Mammalia: Chiroptera) in the state of Rio Grande do Norte, northeastern Brazil. Check List 10(6):1520-1524.

BARROS, M.A.S., MAGALHÃES, R.G. \& RUI, A.M. 2015. Species composition and mortality of bats at the Osório Wind Farm, southern Brazil. Stud. Neotrop. Fauna E. 50(1):31-39.

BARROS, M.A.S., MORAIS, C.M.G., FIGUEIREDO, B.M.B., MOURA JÚNIOR, G.B.D., RIBEIRO, F.F.D.S., PESSOA, D.M.A., ITO, F. \& BERNARD, E. 2017. Bats (Mammalia, Chiroptera) from the Nísia Floresta National Forest, with new records for the state of Rio Grande do Norte, northeastern Brazil. Biota Neotrop. 17(2): e20170351.

BASÍLIO, G.H.N., ARAUJO, J.P.M., VARGAS-MENA, J.C., ROCHA, P.A. \& KRAMER, M.A.F. 2017. Chrotopterus auritus (Chiroptera, Phyllostomidae): first record for the state of Rio Grande do Norte, northeastern Brazil. Check List. 13(3): 2110

BENTO, D.M., BRANDÃO, J.C., DOS SANTOS, D.J., FREITAS, J.I.M., CAMPOS, U.P. \& SOUZA, R.F.R. 2013. Parque Nacional da Furna Feia: o parque nacional com a maior quantidade de cavernas do brasil. In Congresso Brasileiro de Espeleologia (M.A. Rasteiro \& L. Morato, coord.). Sociedade Brasileira de Espeleologia Barreiras, Bahia, p.31-43.

BENTO, D.M., CRUZ, J.B., FREITAS, J.I.M., CAMPOS, U.P. \& OLIVEIRA, A.F. 2017. A mais de 1000! O patrimônio espeleológico potiguar após a descoberta da milésima caverna. In Congresso Brasileiro de Espeleologia (R.M. Rasteiro, C.M. Teixeira-Silva, S.G. Lacerda, coord.). Sociedade Brasileira de Espeleologia, Ouro Preto, p.227-237. 
BELTRÃO, M.G., ZEPPELINI, C.G., FRACASSO, M.P.A. \& LOPEZ, L.C.S. 2015. Bat inventory in a Caatinga area in Northeastern Brazil, with a new occurrence in the state of Paraíba. Neotrop. Biol. Conserv. 10(1):15-20.

BERNARD, E., AGUIAR, L. \& MACHADO, R.B. 2011. Discovering the Brazilian bat fauna: a task for two centuries? Mammal Rev. 41:23-39.

BERNARD, E., PAESE, A., MACHADO, R.B. \& DE SOUZA AGUIAR, L.M. 2014. Blown in the wind: bats and wind farms in Brazil. Nat. Conservação 12(2):106-111.

BRITO, D., AMBAL, R.G., BROOKS, T., DE SILVA, N., FOSTER, M., HAO, W., HILTON-TAYLOR, C., PAGLIA, A., RODRÍGUEZ, J.P. \& RODRÍGUEZ, J.V. 2010. How similar are national red lists and the IUCN Red List? Biol. Conserv. 143(5):1154-1158.

CARVALHO-NETO, F.G., DA SILVA, J.R., SANTOS, N., ROHDE, C., GARCIA, A.C.L. \& MONTES, M.A. 2017. The heterogeneity of Caatinga biome: an overview of the bat fauna. Mammalia, 81(3):257-264

CORDERO-SCHMIDT, E., MEDEIROS-GUIMARÃES, M., VARGASMENA, J.C., CARVALHO, B., FERREIRA, R.L., RODRIGUEZHERRERA, B. \& VENTICINQUE, E.M. 2016. Are leaves a good option in Caatinga's menu? First record of folivory in Artibeus planirostris (Phyllostomidae) in the semiarid forest, Brazil. Acta Chiropterol. 18(2):489-497.

CORDERO-SCHMIDT, E., BARBIER, E., VARGAS-MENA, J.C., OLIVEIRA, P.P., SANTOS, F.A.R., MEDELLÍN, R.A., RODRIGUEZ-HERRERA, B. \& VENTICINQUE, E.M. 2017. Natural history of the Caatinga endemic Vieira's Flower Bat, Xeronycteris vieirai. Acta Chiropterol. 19(2):399-408.

COSTA, L.P., LEITE, Y.L.R., MENDES, S.L. \& DICHTFIELD, A.D. 2005. Conservação de Mamíferos no Brasil. Megadiversidade 1(1):103-112.

CRUZ, J.B., BENTO, D.M., BEZERRA, F.H.R., FREITAS, J.I. \& CAMPOS, U.P. 2010. Diagnóstico Espeleológico do Rio Grande do Norte. Rev. Bras. Espeleo. 1:1-24.

DELGADO-JARAMILLO, M., BARBIER, E. \& BERNARD, E. 2017. New records, potential distribution, and conservation of the Near Threatened cave bat Natalus macrourus in Brazil. Oryx 1-8 doi:10.1017/ S0030605316001186

DÍAZ, M.M., SOLARI, S., AGUIRRE, L.F., AGUIAR, L. \& BARQUEZ, R.M. 2016. Clave de identificación de los murciélagos de Sudamérica/Chave de identificação dos morcegos da América do Sul. Publicación Especial 2, Programa de Conservación de los Murciélagos de Argentina, Tucumán, Argentina, p.160.

FARIAS, F.H.C. 2009. Caracterização biológica e zoneamento ambiental do Parque Estadual do Jiquí/RN, Brasil: subsídios ao plano de manejo. Master thesis, Animal biology department, Science faculty, Lisbon University, Lisbon, Portugal.

FEIJÓ, J.A. \& NUNES, H.L. 2010. Primeiro registro de Myotis nigricans (Schinz, 1821) para o estado do Rio Grande do Norte, nordeste do Brasil. Chiropt. Neotrop. 16(1):531-534.

FEIJÓ, J.A. \& LANGGUTH, A. 2011. Lista de quirópteros da Paraíba, Brasil com 25 novos registros. Chiropt. Neotrop. 17(2):1055-1062.

FEIJÓ, A., ROCHA, P.A. \& ALTHOFF, S.L. 2015a. New species of Histiotus (Chiroptera: Vespertilionidae) from northeastern Brazil. Zootaxa 4048(3):412-427.

FEIJÓ, A., ROCHA, P.A. \& FERRARI, S. F. 2015b. How do we identify Micronycteris sanborni Simmons, 1996 (Chiroptera, Phyllostomidae) reliably and where we can find this species in South America? Pap. Avulsos de Zool. (São Paulo) 55(20).

FERREIRA, R.P., PROUS, X., BERNARDI, L.O.F. \& SOUZA-SILVA, M. 2010. Fauna subterrânea do estado do Rio Grande do Norte: caracterização e impactos. Rev. Bras. Espeleo. 1(1):25-51.

FERREIRA, A.P., CARVALHO-MELO, D. \& LOURES-RIBEIRO, A. 2013. Diclidurus albus Wied-Neuwied, 1820 (Chiroptera: Emballonuridae): first record of the species in the state of Paraíba, Brazil. Check List 9(4):793-796.

FISCHER, E., SANTOS, C.F., CARVALHO, L.F.A.C., CAMARGO, G., CUNHA, N.L., SILVEIRA, M., BORDIGNON, M.O. \& SILVA, C.L. 2015. Bat fauna of Mato Grosso do Sul, southwestern Brazil. Biota Neotrop. 15(2):e20140066. http://dx.doi.org/10.1590/1676-06032015006614 (last access on 25/Apr/2017).
FRICK, W.F., BAERWALD, E.F., POLLOCK, J.F., BARCLAY, R.M.R., SZYMANSKI, J.A., WELLER, T.J., RUSSELL, A.L., LOEB, S.C., MEDELLIN, R.A. \& MCGUIRE, L.P. 2017. Fatalities at wind turbines may threaten population viability of a migratory bat. Biol. Conserv. 209:172-177.

FUREY, N. \& RACEY, P.A. 2016. Conservation ecology of cave bats. In Bats in the Anthropocene: Conservation of bats in a changing world (C.C. Voigt and T. Kingston eds.). Springer, USA, p.606.

GARCIA, A.C.L., LEAL, E.S., ROHDE, C., CARVALHO-NETO, F.G. \& MONTES, M.A. 2014. The bats of northeastern Brazil: a panorama. Anim. Biol. 64(2):141-150.

GARDNER, A.L. 2008. Mammals of South America - Volume 1: Marsupials, Xenarthrans, Shrews, and Bats. Chicago and London, The University of Chicago Press.

GOODWIN, G.G. 1959. Bats of the subgenus Natalus. Am. Mus. Novit. 1977:1-22.

GREGORIN, R. \& TADDEI, V.A. 2002. Chave artificial para a identificação de molossídeos brasileiros (Mammalia, Chiroptera). Mastozool. Neotrop. 9(1):13-32.

GREGORIN, R., MORAS, L.M., ACOSTA, L.H., VASCONCELLOS, K.L., POMA, J.L., DOS SANTOS, F.R. \& PACA, R.C. 2016. A new species of Eumops (Chiroptera: Molossidae) from southeastern Brazil and Bolivia. Mamm. Biol. 81(3):235-246.

GURGEL-FILHO, N.M., FEIJÓ, A. \& LANGGUTH, A. 2015. Pequenos Mamíferos do Ceará (Marsupiais, Morcegos e Roedores sigmodontineos) com discussão taxonômica de algumas espécies. Rev. Nordestina Biol. 23(3):3-150.

GUTIÉRREZ, E. \& MARINHO-FILHO, J. 2017. The mammalian faunas endemic to the Cerrado and the Caatinga. ZooKeys 644:105-157

HEIN, C.D. \& SCHIRMACHER, M.R. 2016. Impact of wind energy on bats: a summary of our current knowledge. Hum-Wildl. Interact. 10(1):19-27.

ICMBio/MMA - Instituto Chico Mendes de Conservação da Biodiversidade/ Ministério de Meio Ambiente. 2016. Sumário Executivo do Livro Vermelho da Fauna Ameaçada de Extinção. Distrito Federal, Brasília, Brazil, p. 1-17.

IUCN - International Union for Conservation of Nature. 2016. The IUCN Red List of Threatened Species. Version 2016-3. http://www.iucnredlist.org (last access on 17/Apr/2017).

IDEMA - Instituto De Desenvolvimento Sustentável e Meio Ambiente. 2015. Anuário estatístico 2015. Rio Grande do Norte: Governo do Rio Grande do Norte. http://www.idema.rn.gov.br/Conteudo.asp?TRAN=ITEM\&TARG= $1357 \& A C T=$ null\&PAGE $=0 \& P A R M=$ null $\&$ LBL $=$ Socioecon $\%$ C3\%B4mic os (last access on 15/Dec/2016).

INPE/SOS MATA ATLANTICA. 2014. Atlas dos remanescentes florestais da Mata Atlântica período 2011-2012 - relatório técnico. Fundação SOS Mata Atlântica, Instituto Nacional de Pesquisas Espaciais -INPE, São Paulo, p.1-60.

JONES, J.K. \& HOOD, C.S. 1993. Synopsis of South American bats of the family Emballonuridae. Occas. Pap. Tex. Tech. Univ. Mus. 155:1-32.

LEAL, I.R., TABARELLI, M. \& SILVA, J.M.C. 2003. Ecologia e conservação da Caatinga. 3 ed. Editora Universitária da Universidade Federal de Pernambuco, Recife, Brasil.

LEAL, E.S.B., AZEVÊDO-JÚNIOR, S.M., NOVA, F.V.P.V., QUEIRÓZGUERRA, D. \& TELINO-JÚNIOR, W.R. 2013. Updated compilation of bat species (Chiroptera) for the Brazilian state of Sergipe, including new records. Chiropt. Neotrop. 19(1):1163-1178.

LEAL, E.S.B., SILVA, D.Q., FIGUEIREDO-RAMALHO, D., MILLER, B.G., PASSOS-FILHO, P.B., PRADO-NETO, J.G., QUEIRÓZ-GUERRA, D., MOURA, G.J.B., LYRA-NEVES, R.M. \& TELINO-JÚNIOR, W.R. 2014. Extension of the geographical distribution of Lonchophylla dekeyseri Taddei, Vizotto and Sazima, 1983 (Chiroptera: Phyllostomidae): new record in northeastern Brazil. Chiropt. Neotrop. 19(2):1220-1225.

MACSWINEY, G., CRISTINA, M., CLARKE, F.M. \& RACEY, P.A. 2008. What you see is not what you get: the role of ultrasonic detectors in increasing inventory completeness in Neotropical bat assemblages. J. Appl. Ecol. 45(5):1364-1371. 
MARES, M.A., WILLIG, M.R., SRTEILEIN, K.E. \& LACHER JR. T.E. 1981 The mammals of northeastern Brazil: a preliminary assessment. Ann. Carnegie Mus. 50:81-137.

MARES, M.A., WILLIG, M.R. \& LACHER JR, T.E. 1985. The Brazilian Caatinga in South American zoogeography: tropical mammals in a dry region. J. Biogeogr. 12:57-69.

MORATELLI, R., PERACCHI, A. L., DIAS, D. \& DE OLIVEIRA, J. A. 2011 Geographic variation in South American populations of Myotis nigricans (Schinz, 1821) (Chiroptera, Vespertilionidae), with the description of two new species. Mamm. Biol. 76(5): 592-607.

MORATELLI, R. \& DIAS, D. 2015. A new species of nectar-feeding bat, genus Lonchophylla, from the Caatinga of Brazil (Chiroptera, Phyllostomidae). ZooKeys 514:73-91.

NOGUEIRA, M.R., LIMA, I.P., MORATELLI, R., TAVARES, V.C., GREGORIN, R. \& PERACCHI, A.L. 2014. Checklist of Brazilian bats, with comments on original records. Check List 10(4):808-821.

NUNES, H.L., FEIJÓ, J.A., BELTRÃO, M., LOPEZ, L.C.S. \& FRACASSO, M.P.A. 2013. First and easternmost record of Molossops temminckii (Burmeister, 1854) (Chiroptera: Molossidae) for the state of Paraíba, northeastern Brazil. Check List 9(2):436-439.

O'SHEA, T.J., CRYAN, P.M., HAYMAN, D.T., PLOWRIGHT, R.K. \& STREICKER, D.G. 2016. Multiple mortality events in bats: a global review. Mammal Rev. 46(3):175-190.

PAGLIA, A.P., FONSECA, G.A.B., RYLANDS, A.B., HERRMANN, G., AGUIAR, L.M.S., CHIARELLO, A.G., LEITE, Y.L.R., COSTA, L.P., SICILIANO, S., KIERULFF, M.C.M., MENDES, S.L., TAVARES. V.C., MITTERMEIER, R.A. \& PATTON, J.L. 2012. Lista Anotada dos Mamíferos do Brasil. 2 ed. Occ. Pap. In Conservat. Biology.

REIS, N.R., PERACCHI, A.L., PEDRO, W.A. \& LIMA, I.P. 2007. Morcegos do brasil. Universidade Estadual de Londrina, Londrina, Brazil.

ROCHA, P.A., FEIJÓ, A., PEDROSO, M.A., \& FERRARI, S.F. 2015. First record of the big free-tailed bat, Nyctinomops macrotis (chiroptera, molossidae), for the semi-arid caatinga scrublands of northeastern Brazil Mastoz. Neotrop. 22(1):195-200.

ROCHA, P.A., BRANDÃO, M.V., GARBINO, G.S.T., CUNHA, I.N. \& AIRES, C.C. 2016. First record of Salvini's big-eyed bat Chiroderma salvini Dobson, 1878 for Brazil. Mammalia 80(5):573-578.

ROCHA, P.A., SOARES, F.A., DIAS, D., MIKALAUSKAS, J.S., VILAR, E.M., FEIJÓ, A., \& DAHER, M. R. 2017. New records of Micronycteris schmidtorum Sanborn, 1935 (Phyllostomidae, Chiroptera) for northeastern Brazil. Mastoz. Neotrop. 24:1-8.

SAGOT, M. \& CHAVERRI, G. 2015. Effects of roost specialization on extinction risk in bats. Conserv. Biol. 29(6):1666-1673.

SAMPAIO, E., LIM, B. \& PETERS, S. 2016. Lonchophylla mordax. The IUCN Red List of Threatened Species 2016. e.T12267A22038521. http://dx.doi. org/10.2305/IUCN.UK.2016-3.RLTS.T12267A22038521.en.
SANBORN, C.C. 1937. American bats of the subfamily Emballonuridae. Field Mus. Nat. Hist. Zool. Series 29(24):321-354.

SANTOS, J.C., LEAL, I.R., ALMEIDA-CORTEZ, J.S., FERNANDES, G.W. \& TABARELLI, M. 2011. Caatinga: the scientific negligence experienced by a dry tropical forest. Trop. Conserv. Sci. 4(3):276-286.

SCHUSTER, E., BULLING, L. \& KÖPPEL, J. 2015. Consolidating the state of knowledge: a synoptical review of wind energy's wildlife effects. Environ. Manage. 56(2):300-331.

SILVA, S.S., DIAS, D., MARTINS, M.A., GUEDES, P.G., DE ALMEIDA, J.C., CRUZ, A.P., SERRA-FREIRE, N.M., DAMASCENA, J.S. \& PERACCHI, A.L. 2015. Bats (Mammalia: Chiroptera) from the caatinga scrublands of the Crateús region, northeastern Brazil, with new records for the state of Ceará. Mastozool. Neotrop. 22(2):335-348.

SILVA, C.R. \& BERNARD, E. 2017. Bioacoustics as an important complementary tool in bat inventories in the Caatinga drylands of Brazil. Acta Chiropterol. 19(2):409-418.

SIMMONS, N.B. 1996. A new species of Micronycteris (Chiroptera, Phyllostomidae) from northeastern Brazil: with comments on phylogenetic relationships. Am. Mus. Novit. 3158:1-34.

SIMMONS, N.B. \& VOSS, R.S. 1998. The mammals of Paracou, French Guiana, a Neotropical lowland rainforest fauna. Part 1, Bats. Bull. Am. Mus. Nat. Hist. 237:1-219.

SOLARI, S. \& MARTÍNEZ-ARIAS, V. 2014. Cambios recientes en la sistemática y taxonomía de murciélagos Neotropicales (Mammalia: Chiroptera). Therya 5(1):167-196.

TEJEDOR, A. \& DAVALOS, L. 2016. Natalus espiritosantensis. The IUCN Red List of Threatened Species 2016: e.T136448A21983924. http://dx.doi. org/10.2305/IUCN.UK.2016-2.RLTS.T136448A21983924.en (last access on $15 / \mathrm{Feb} / 2017)$.

VARGAS-MENA, J.C., CORDERO-SCHMIDT, E., BENTO, D.M., RODRÍGUEZ-HERRERA, B., MEDELLÍN, R.A., VENTICINQUE, E.M in press. Diversity of cave bats in the Brazilian tropical dry forest of Rio Grande do Norte State. Mastozool. Neotrop.

VELLOSO, A.L., SAMPAIO, E.V.S.B. \& PAREIN, F.G.C. 2002. Ecorregiões propostas para o bioma Caatinga - Resultado do Seminário de Planejamento Ecorregional da Caatinga. Associação Plantas do Nordeste, Instituto de Conservação Ambiental, The Nature Consercancy, Recife, p. 1-76.

VILAR, E.M., NUNES, H., NASCIMENTO, J.L. \& ESTRELA, P.C. 2015. Distribution extension of Ametrida centurio Gray, 1847 (Chiroptera, Phyllostomidae): first record in the Brazilian Atlantic Forest. Check List 11(1): 1503

WEBSTER, W.D. 1993. Systematics and evolution of bats of the genus Glossophaga. Tex. Tech. Univ. Mus. Spec. Publ. 36:1-184.

WILLIG, M.R. 1983. Composition, microgeographic variation and sexual dimorphism in Caatingas and Cerrado bat communities from northeast Brazil. Bull. Carnegie Mus. Nat His. 23:1-131. 